\title{
Konsumsi dan tingkat subsistensi petani di Kampung Sei Berbari, Kecamatan Pusako, Kabupaten Siak Provinsi Riau
}

\author{
Mardiana*, Rita Yani Iyan, \& Yelly Zamaya
}

Fakultas Ekonomi dan Bisnis Universitas Riau

\begin{abstract}
Abstrak: Artikel ini bertujuan untuk menganalisis konsumsi dan tingkat subsistensi rumah tangga petani. Penelitian ini dilakukan di Kampung Sungai Berbari Kecamatan Pusako Kecamatan Siak Provinsi Riau. Sampel diambil sebanyak 55 rumah tangga petani. Sampel dikelompokkan kepada petani berlahan besar ( $>2$ hektar), berlahan sempit $(<2$ hektar) dan penggarap (sebagian besar lahan yang dikelola milik orang lain). Nilai tukar pendapatan petani dihitung dengan konsep nilai tukar subsisten (NTS). Regresi liner berganda digunakan untuk mengetahui faktor yang mempengaruhi tingkat subsistensi petani. Hasil kajian mendapati konsumsi rumah tangga petani berbanding lurus dengan luas lahan yang dimiliki. Konsumsi pangan petani penggarap termasuk kategori rentan atau rawan pangan dan petani penggarap belum sejahtera karena persentase pengeluaran untuk pangan lebih besar dibandingkan persentase pengeluaran nonpangan. Man land ratio dan dependency ratio berpengaruh positip dan signifikan terhadap subsistensi rumah tangga petani. Petani pemilik lahan sendiri memiliki tingkat subsistensi yang lebih rendah dibanding petani yang menggarap lahan pihak lain.
\end{abstract}

Katakunci: konsumsi; tingkat subsistensi; petani penggarap; rasio lahan-manusia.

\begin{abstract}
This article aims to analyze the consumption and subsistence level of farm households. This research was conducted in Sungai Berbari Village, Pusako District, Siak District Province of Riau. Samples were taken as many as 55 farm households. Samples were grouped with large-scale farmers ( $>2$ hectares), narrow land ( $<2$ hectares) and tenants (most of the land that was managed by others). Farmer income exchange rates are calculated using the concept of subsistence exchange rates (NTS). Multiple linear regression is used to determine the factors that influence the level of subsistence of farmers. The results of the study found that household consumption of farmers is directly proportional to the area of land owned. Food consumption of smallholder farmers is categorized as vulnerable or food insecure and smallholders are not prosperous because the percentage of food expenditure is greater than the percentage of non-food expenditure. Man land ratio and dependency ratio have positive and significant influence on subsistence of farm households. Farmers owning land have lower subsistence levels compared to farmers who work on other parties' land.
\end{abstract}

Keywords: consumption; subsistence level; tenant farmers; land-man ratio

JEL Classification: E21, Q15 


\section{PENDAHULUAN}

Peran sektor pertanian dalam penyerapan tenaga kerja selama krisis dan beberapa tahun terakhir terjadi penurunan nilai tukar petani dan penurunan upah buruh di pedesaan. Hal ini menunjukkan adanya pertambahan angkatan kerja di Indonesia yaitu $1,2 \%$ atau sekitar 2 juta orang setiap tahun. Perubahan di pedesaan sebagai dampak dari modernisasi pedesaan paling mudah dilihat dari tingkat kesejahteraan masyarakatnya. Kondisi ekonomi masyarakat secara fisik dapat dilihat dari pemukiman dan ketersedian sarana prasana umum yang ada di pedesaan. Terkait dengan kesejahteraan ekonomi masyarakat, dimensi yang paling mudah dilihat secara sosial adalah strategi nafkah yang secara umum sering diartikan sebagai mata pencaharian masyarakat (Mardiyaningsih et al., 2010).

Pembangunan pertanian dan kesejahteraan petani belum bisa berjalan karena pembangunan pertanian dijalankan tanpa landreform. Pemerintah telah memprogramkan untuk melakukan reforma agraria seluas 9 juta ha lahan untuk dibagikan ke petani dalam kurun waktu lima tahun yakni dari tahun 2015 sampai 2019.

Hal ini merupakan terobosan yang sangat signifikan, di tengah sulitnya redistribusi lahan kepada petani. Jika ini bisa direalisasikan, maka selain secara makro mampu menyediakan luasan lahan nasional yang memadai, juga akan meningkatkan struktur penguasaan lahan di tingkat petani. Penguasaan lahan yang sempit dan bukan milik merupakan penyebab utama rendahnya pendapatan keluarga petani selama ini (Nurlinda, 2019)

Struktur pengeluaran rumah tangga dipengaruhi oleh beberapa hal diantaranya adalah: perubahan pengeluaran menurut waktu, perbedaan antar selera, perbedaan pendapatan dan lingkungan. Perilaku pengeluaran rumah tangga yang tersedia harus sesuai dengan tingkat kemampuan pendapatan yang diperoleh dan bagaimana mendistribusikannya, agar tidak terguncang untuk memenuhi kebutuhan

Pertanian subsisten berkontribusi tidak hanya bagi pengembangan pertanian masyarakat pedesaan, tetapi juga bagi negara secara keseluruhan. Oleh karena itu, budibudaya berkelanjutan membutuhkan penanggulangan berbagai masalah yang menghambat pertanian subsisten di masyarakat pedesaan. Ini menunjukkan bahwa penting untuk fokus pada pengembangan intervensi yang akan berdampak positif pada praktik pertanian subsisten. Intervensi ini mungkin bekerja untuk meremajakan praktik pertanian subsisten melalui pendidikan, penelitian pertanian, dan kredit mikro; untuk mengurangi kerugian pascapanen; mengembangkan pasar; dan bahkan untuk memberikan subsidi secara langsung kepada petani (Onakuse, 2012).

\section{METODE}

Penelitian ini dilakukan di Kampung Sungai Berbari Kecamatan Pusako Kecamatan Siak Provinsi Riau. Daerah ini merupakan salah satu penerima program Tanah Objek Reformasi Agraria (TORA). Kampung Sungai Berbari berpenduduk 806 jiwa terdiri dari 420 laki-laki dan 386 perempuan dalam 196 rumah tangga. Sebagian besar penduduknya bermata pencaharian petani.

Data utama yang digunakan dalam penelitian ini ialah data primer melalui survey atas responden sampel. Sampel diambil sebanyak 55 rumah tangga dari 196 rumah tangga populasi yang dikelompokkan kepada petani berlahan besar ( $>2$ 
hektar), berlahan sempit $(<2$ hektar) dan penyakap/penggarap (sebagian besar lahan yang dikelola milik pihak lain).

Metoda analisis yang dibangun dan digunakan disesuaikan dengan tujuan penelitian. Nilai tukar pendapatan petani dihitung dengan konsep nilai tukar subsisten (NTS). NTS dirumuskan sebagai berikut: $\unrhd \_$j)]

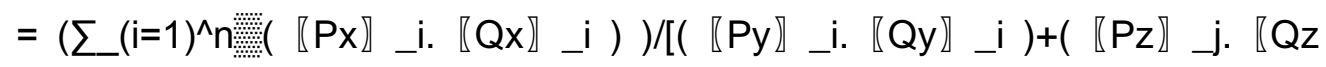

Keterangan:

NTS = Nilai Tukar Subsisten;

Px; = Harga komoditas Pertanian ke i;

Qx, = Produksi komoditas Pertanian ke i;

Py, = Harga Produk Konsumsi ke i;

Pzj = Harga Input Produksi ke i;

Qy, = Jumlah Produk Konsumsi ke i;

$\mathrm{Qz}=$ Jumlah Input Produksi ke i;

Penentu subsistensi menggunakan model yang digunakan liner berganda dengan variabel terikat adalah tingkat subsistensi (rasio untuk pemenuhan kebutuhan pangan) dengan variabel bebasnya adalah rasio tanah manusia (man land ratio), angka ketergantunagn rumah tangga), status pemilikan lahan (pemilik atau penyakap).

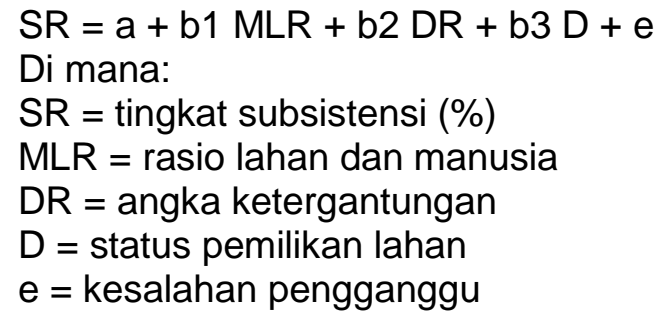

\section{HASIL DAN PEMBAHASAN}

Pada tingkat pendapatan usahatani yang rendah, rumah tangga petani akan memaksimalkan pendapatannya dengan jalan mengkombinasikan kegiatannya Asnawi (2007) menyatakan bahwa pendapatan usahatani masih kurang mampu mendukung kehidupan petani secara layak. Hal ini didukung dengan kondisi di lapangan yaitu semakin kecilnya luas areal kepemilikian lahan usahatani kelapa sawit yang disebabkan oleh perpecahan lahan (fragmentasi) karena pewarisan, alih fungsi lahan, serta rendahnya produktifitas karena harga TBS yang relatif berfluktuasi dan cenderung menurun (Asnawi, 2007).

\section{Luas dan Status Kepemilikan Lahan}

Skala usahatani dapat ditunjukan dari luas lahan yang dikelola petani, baik milik sendiri maupun milik orang lain, sebagai salah satu modal utama dalam menjalankan usahatani. Luas lahan yang dimiliki petani sangat mempengaruhi besar kecilnya pendapatan karena akan berhubungan langsung dengan hasil produksi. Pemaksimalan luas lahan menjadi salah satu syarat dalam pengembangan usahatani dan optimalisasi pendapatan. Tabel 1 menunjukan cakupan luas lahan yang digarap petani responden. 
Tabel 1 Jumlah Responden Menurut Luas Lahan

\begin{tabular}{cccc}
\hline No & Luas Lahan (ha) & Jumlah Responden (orang) & Persentase (\%) \\
\hline 1 & $<1$ & 14 & 25.45 \\
2 & $1-2$ & 26 & 47.27 \\
3 & $2-4$ & 9 & 16.36 \\
4 & $>4$ & 6 & 10.91 \\
\hline & Jumlah & 55 & 100.00 \\
\hline
\end{tabular}

Sumber: Hasil Analisis Data Survey, 2019

Sehubungan dengan status kepemilikan lahan pertanian, petani di Kampung Sungai Berbari terdiri atas kelompok petani penggarap dan petani pemilik. Petani penggarap merupakan kelompok petani yang hanya memiliki status pinjam dimana lahan yang diusahakannya merupakan bukan milik mereka. Sedangkan kelompok petani pemilik merupakan petani yang mengolah tanah miliknya sendiri sebagai lahan tani.

Tabel 2 menunjukan jumlah petani responden berdasarkan status kepemilikan lahan yang diusahakan dalam penelitian ini yang menunjukan bahwa sebagian besar petani merupakan kelompok petani pemilik, yaitu sebanyak 36 responden $(65,5 \%)$, sedangkan kelompok petani penggarap sebanyak 19 responden (34,5\%) dari keseluruhan responden.

Tabel 2 Jumlah Responden Menurut Status Kepemilikan

\begin{tabular}{cccc}
\hline No & Pendidikan & Jumlah Responden (orang) & Persentase (\%) \\
\hline 1 & Pemilik & 36 & 65.5 \\
2 & Penggarap & 19 & 34.5 \\
\hline & Jumlah & 55 & 100.00 \\
\hline
\end{tabular}

Sumber: Hasil Analisis Data Survey, 2019

\section{Pola Penguasaan Lahan}

Pola penguasan lahan dalam pertanian pedesaan diklasifikasikan statusnya menjadi hak milik, sewa, sakap (bagi hasil) dan gadai. Pada masyarakat pedesaan ketiga bentuk penguasaan lahan tersebut pada umumnya mempunyai aturan tertentu yang disepakati meskipun tanpa perjanjian tertulis maupun tanpa menggunakan jaminan surat-surat berharga yang secara formal disahkan oleh pemerintah (misalnya: sertifikat lahan atau SKGR) (Darwis, 2008)

Pada masyarakat kampung, kepemilikan lahan secara umum adalah milik kampung/lahan komunal. Sebagian anggota komunitas mendapat hak untuk menguasai dalam hal ini sebagai pengelola lahan dimana anggota komunitas tersebut berhak untuk menggarap lahan kampung. Hak garap ini jika tidak sanggup dilakukan oleh satu keluarga dapat dialihkan dengan anggota komunitas yang lain dengan sistem bagi hasil (sakap). Namun lahan-lahan ini tidak dapat diperjual belikan dan menuruti aturan adat dalam pola pengelolaannya. Pola penguasaan lahan dalam bentuk sewa dan gadai tidak ditemukan dalam masyarakat Kampung Sungai Berbari.

Pola hubungan sosial agraria antara pemilik lahan dan buruh tani dalam Kampung Sungai Berbari juga relatif seimbang. Pada umumnya untuk memenuhi kebutuhan tenaga kerja di luar tenaga kerja rumahtangga atau keluarga, sistem yang digunakan adalah mengambil buruh luar. Bagi buruh tani yang membantu dan tidak memiliki lahan untuk menanam masih menggunakan sistem bagi hasil 
timbangan buah sawit. Hal tersebut membuktikan bahwa tingkat kepercayaan pemilik lahan kepada buruh tani sangat tinggi meskipun tidak ada pengawasan dalam pengerjaan lahan dan penimbangan.

\section{Nilai Tukar Petani di Kampung Sungai Berbari}

Kondisi kolektivitas di kawasan kajian dinilai sama padahal terdapat kondisi modal sosial yang berbeda. Hal tersebut dikarenakan adanya faktor kepercayaan yang sama di kawasan kajian. Jika merujuk pada proses pembentukkan modal sosial mengenai kolektifitas sebagai basis pengembangan ekonomi lokal, pembentukkan modal sosial ditopang oleh adanya kepercayaan dan norma yang berlaku di kalangan masyarakat. Hampir seluruh tahapan subsistem kolektifitas sangat membutuhkan kepercayaan berupa investasi finansial secara kolektif, dari mulai pengadaan saprotan hingga tabungan simpan pinjam bersama.

NTP berkaitan dengan kemampuan daya beli petani dalam membiayai kebutuhan hidup rumah tangganya. Mayoritas penduduk Indonesia memanfaatkan sumber daya alam yang ada untuk memenuhi kebutuhan hidupnya dengan salah satu caranya adalah dengan bertani. Namun pada kenyataannya sumber daya alam tidak sepenuhnya dimanfaatkan. Perlu diketahui bahwa dua per tiga penduduk Indonesia tinggal di daerah pedesaan dan sebagian besar di antaranya masih menggantungkan hidupnya pada sektor pertanian (Ruauw, 2010)

Menurut Simatupang (2007) hasil tukar komoditas pertanian cenderung menurun setiap tahun. Artinya, kemerosotan dalam nilai tukar hasil pertanian, atau penurunan tingkat harga pertanian relatif terhadap harga barang dan jasa lain mengakibatkan penurunan pendapatan riil petani (Simatupang, 2007). Fungsi dari indeks harga yang diterima dan indeks harga yang dibayar oleh petani (Hedayana, 2001)

Rachmad (2000) menjelaskan bahwa daerah dengan pangsa komoditas padi tinggi menghasilkan NTP relatif konstan. Daerah dengan pangsa perkebunan dominan NTP cenderung menurun, sedangkan daerah dengan pangsa konsumsi makanan tinggi menghasilkan NTP yang cenderung lebih rendah (Rachmat, 2000).

\section{Pendapatan}

Kontribusi pendapatan petani dari usahatani paling besar yaitu pada petan berlahan sempit yaitu sebesar $94 \%$ selanjutnya petani berlahan luas, kontribusi usahatani berkontribusi sebesar $88 \%$ dan yang paling sedikit adalah petani penggarap, kontribusi dari usahatani sebesar $81 \%$. Rata-rata pendapatan dari nonusahatani pada petani penggarap cukup berkontribusi yaitu mencapai $15 \%$ dari rata-rata pendapatan per bulan.

Walaupun pada komoditas kelapa sawit petani sering mengeluh karena pendapatan tidak sesuai denga yang diharapkan, namun petani tetap bertahan pada komoditas kelapa sawit dengan alasan biaya produksi tidak setinggi komoditas lain. Kontribusi pendapatan pada petani penggarap ini menunjukkan bahwa petani penggarap harus mencari tambahan pendapatan dari non kelapa sawit untuk mencukupi kebutuhan hidupnya. Pada petani penggarap, kontribusi non-pertanian ada sebesar $4 \%$ dari hasil pekerjaan lain seperti ojeg, pedagang, buruh dan lainnya. Petani berlahan luas tidak ada kontribusi dari non-pertanian karena sudah tercukupi dari hasil kelapa sawit. 


\section{Penentu Subsistensi Petani}

Penentu subsistensi menggunakan model yang digunakan liner berganda dengan variabel terikat adalah tingkat subsistensi (rasio untuk pemenuhan kebutuhan pangan) dengan variabel bebasnya adalah rasio tanah manusia (man land ratio), angka ketergantunagn rumah tangga), status pemilikan lahan (pemilik atau penyakap).

Hasil analisis regresi atas 55 responden petani di Kampung Sungai Berbari diperoleh persamaan sebagai berikut:

$$
\begin{aligned}
& (\mathrm{SR})^{\wedge}=\begin{array}{c}
65,78+11,21 \mathrm{MLR}^{* *}+27,54 \mathrm{DR}^{*}-15,45 \mathrm{D}^{* *} \\
(3,25) \quad(2,45) \quad(3,85)
\end{array} \\
& \mathrm{R} 2=0,68 \\
& \left.\left.{ }^{* *}\right) \text { sign } 1 \%,{ }^{*}\right) \text { sign } 5 \%
\end{aligned}
$$

Persamaan di atas merupakan bentuk hubungan variabel variabel bebas penentu tingkat subistensi petani di Kampung Sungai Berbari. Semakin besar rasio manusia/ anggota rumah tangga (man land ratio) terhadap pengelolaan lahan akan semakin besar subsistensinya atau komponen konsumsi kebutuhan pangan dalam keluarga semakin meningkat.

Beberapa faktor yang diduga menjadi penyebab menurunnya tingkat konsumsi petani makin sempitnya lahan yang dimiliki petani (Wiryono, 1997). Luas lahan merupakan salah satu faktor utama dalam peningkatan kesejahteraan, semakin luas lahan yang dikelola akan semakin kecil konsumsi untuk kebutuhan pangan, dan konsumsi untuk kebutuhan non-pangan semakin besar (Sugesti et al., 2015). Kajian ini sesuai dengan temuan dari Fatimah dan Syamsiah (2018) yang mendapati luas lahan petani bepengaruh positip terhadap pengeluaran non-makanan (Fatimah \& Syamsiah, 2018)

Angka ketergantungan (dependency ratio) petani di Sungai Berbari berbanding lurus dengan tingkat subsistensi. Besarnya ketergantungan anggota rumah tangga menyebbakan kebutuhan pangan menjadi bagian terbesar dari konsumsi dalam rumah tangga. Seperti halnya Humaidi et al. (2015) menyebutkan jumlah anggota rumah tangga berpengaruh positip terhadap pengeluaran makanan. Temuan lainnya juga adanya kaitan antara ketahanan pangan dan rumah tangga petani (Arida et al., 2015).

Ada dua jenis responden yang diambil dalam penelitian ini, petani pemilik lahan sendiri dan petani yang menggarap lahan milik pihak lain. Petani pemilik lahan sendiri memiliki tingkat subsistensi yang lebih rendah dibanding petani yang menggarap lahan pihak lain. Artinya penggarap memiliki persentase pengeluaran untuk konsumsi pangan lebih besar dibanding petani pemilik.

\section{KESIMPULAN}

Pendapatan petani dari usahatani paling besar yaitu pada petani petani berlahan luas. Rata-rata pendapatan dari non-usahatani pada petani penggarap cukup berkontribusi yaitu mencapai $15 \%$ dari rata-rata pendapatan per bulan. Pengeluaran rumah tangga dapat dikelompokkan menjadi dua bagian, yaitu pengeluaran untuk pangan dan pengeluaran untuk non-pangan. Besaran pengeluaran rumah tangga ini dipengaruhi oleh jumlah tanggungan rumah tangga dan juga kebiasaan setiap keluarga dalam memenuhi kebutuhannya. Pengeluaran rumah tangga petani Kampung Sungai Berbari berbanding lurus dengan luas lahan yang dimiliki. Pengeluaran pangan petani penggarap termasuk kategori rentan atau 
rawan pangan dan petani penggarap belum sejahtera karena persentase pengeluaran untuk pangan lebih besar dibandingan persentase pengeluaran nonpangan. Namun untuk petani berlahan yang memiliki lahan (sempit dan luas) sudah sejahtera karena persentase pengeluaran pangannya lebih kecil dibandingkan persentase pengeluaran non-pangannya.

Semakin besar rasio manusia/anggota rumah tangga (man land ratio) terhadap pengelolaan lahan akan semakin kecil konsumsi kebutuhan pangan dalam keluarga semakin meningkat. Luas lahan petani bepengaruh positip terhadap pengeluaran non-makanan. Besarnya ketergantungan anggota rumah tangga menyebabkan kebutuhan pangan menjadi bagian terbesar dari konsumsi dalam rumah tangga. Petani pemilik lahan sendiri memiliki tingkat subsistensi yang lebih rendah dibanding petani yang menggarap lahan pihak lain.

Petani penggarap harus lebih produktif mengusahakan lahan yang dikerjakannya melalui tumpang sari tanaman sehingga bisa dikomersilkan seperti palawija dan tanaman umur pendek. Pengeluaran petani untuk kebutuhan nonpangan harus ditingkatkan dengan mengubah pola konsumsi pangan dari barang kebutuhan pokok yang dibeli digantikan dengan bahan pokok yang ditanam di sekitar. Penghasilan dari kerja atau menggarap lahan milik orang lain digunakan untuk memberi/membayar kebutuhan lainnya.

\section{DAFTAR PUSTAKA}

(1) Arida, A., Sofyan, S., \& Fadhiela, K. (2015). Analisis Ketahanan Pangan Rumah Tangga Berdasarkan Proporsi Pengeluaran Pangan dan Konsumsi Energi (Studi Kasus pada Rumah Tangga Petani Peserta Program Desa Mandiri Pangan di Kecamatan Indrapuri Kabupaten Aceh Besar). Jurnal Agrisep, 16(1), 20-34.

(2) Asnawi, R. (2007). Analisis Usahatani Sistem Tanam Double Row pada Tanaman Ubi Kayu (Manihot esculenta) di Lampung. Jurnal Pengkajian dan Pengembangan Teknologi Pertanian, 10(1), 39-47. Retrieved from http://ejurnal.litbang.pertanian.go.id/index.php/jpengkajian/article/view/1451

(3) Darwis, R. (2008). Keragaan Penguasaan Lahan sebagai Faktor Utama Penentu Pendapatan Petani. Seminar Nasional Dinamika Pembangunan Pertanian dan Perdesaan: Tantangan dan Peluang bagi Peningkatan Kesejahteraan Petani. Bogor: Pusat Analisis Sosial Ekonomi dan kebijakan Pertanian, Departemen Pertanian.

(4) Fatimah, N., \& Syamsiah, N. (2018). Proporsi Pengeluaran Rumah Tangga Petani Padi Di Desa Patimban, Kecamatan Pusakanagara, Kabupaten Subang, Jawa Barat. Mimbar Agribisnis, 4(2), 184-196.

(5) Hedayana, R. (2001). Analisis Fakto r-FaktorYang Mempengaruhi Nilai Tukar Petani. Bogor: Pusat Penelitian dan Pengembangan Sosial Ekonomi Pertanian, Badan Penelitian dan Pengembangan Pertanian.

(6) Humaidi, E., Amin, Z., \& Suryati, N. (2015). Pola Pengeluaran Rumah Tangga Petani Karet Di Desa Binjai Kecamatan Muara Kelingi. Societa, 4(1), 54-58.

(7) Mardiyaningsih, D. I., Dharmawan, A. H., \& Tonny, F. (2010). Dinamika Sistem Penghidupan Masyarakat Tani Tradisional dan Modern di Jawa Barat. Sodality, 115145.

(8) Nurlinda. (2019). Perolehan Tanah Obyek Reformasi Agraria (TORA) Yang Berasal Dari Kawasan Hutan: Permasalahan Dan Pengaturannya. Veritas et Justitia, 4(2), 253-273. https://doi.org/10.25123/vej.2919 
(9) Onakuse. (2012). The Future of Subsistence Agriculture in the Rural Community of Uzanu, Edo State, Nigeria. Journal of Agriculture, Food Systems, and Community Development, 3(1), 61-71. https://doi.org/10.5304/jafscd.2012.031.021

(10) Rachmat, P. (2000). Analisis Nilai Tukar Petani Indonesia. Disertasi. Bogor, Bogor: Institut Pertanian Bogor.

(11) Ruauw, E. (2010). Nilai Tukar Petani Sebagai Indikator Kesejateraan Petani. ASE, $6(2), 1-8$.

(12) Simatupang, P. (2007). Analisis Kritis Terhadap Paradigma dan Kerangka Dasar Kebijakan Ketahanan Pangan Nasional. Forum Penelitian Agro Ekonomi (FAE), 25(1), 1-18. https://doi.org/10.21082/fae.v25n1.2007.1-18

(13) Sugesti, M.T., Abidin, Z., \& Kalsum, U. (2015). Analisis Pendapatan Dan Pengeluaran Rumah Tangga Petani Padi Desa Sukajawa, Kecamatan Bumiratu Nuban, Kabupaten Lampung Tengah. Jurnal Ilmu-IImu Agribisnis, 3(3), 251-259. Retrieved from https://jurnal.fp.unila.ac.id/index.php/JIA/article/view/1049

(14) Wiryono. (1997). Kekalahan Manusia Petani. Yogyakarta, Indonesia: Rineka Cipta. 